RPP-RPT-42583

Revision 0

\title{
Synthetic Sling Failure - Evaluations and Recommendations
}

Prepared for the U.S. Department of Energy

Assistant Secretary for Environmental Management

Contractor for the U.S. Department of Energy

Office of River Protection under Contract DE-AC27-08RV14800

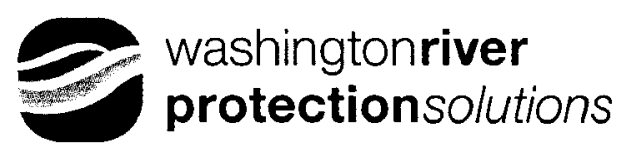

P.O. Box 850

Richland, Washington 99352

\section{Approved for Public Release; Further Dissemination Untimited}


RPP-RPT-42583

Revision 0

\section{Synthetic Sling Failure - Evaluations and Recommendations}

C. S. Henderson

T. C. Mackey

Washington River Protection Solutions

Date Published

October 2009

Prepared for the U.S. Department of Energy

Assistant Secretary for Environmental Management

Contractor for the U.S. Department of Energy

Office of River Protection under Contract DE-AC27-08RV14800

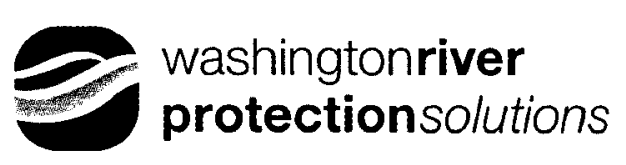

P.O. Box 850

Richland, Washington

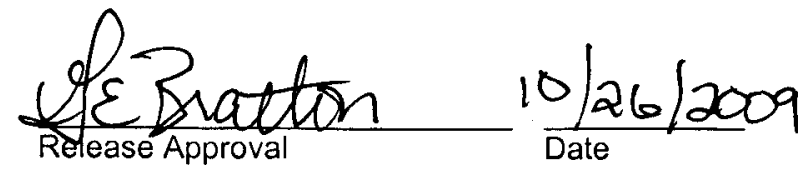

Approved for Public Release;
Further Dissemination Unlimited 
RPP-RPT-42583

Revision 0

TRADEMARK DISCLAIMER

Reference herein to any specific commercial product, process,

or service by trade name, trademark, manufacturer, or

otherwise, does not necessarily constitute or imply its

endorsement, recommendation, or favoring by the United

States Government or any agency thereof or its contractors or

subcontractors.

This report has been reproduced from the best available copy. 


\section{EXECUTIVE SUMMARY}

The information and evaluations provided in this report were compiled to address the recurring problem of synthetic sling failure. As safety is the number one priority in all work aspects, a solution must be devised to prevent accidents from occurring. A total of thirteen cases regarding synthetic sling failure were evaluated in order to determine their causes, effects, and preventative measures. From the collected data, it was found that all cases in which the synthetic sling contacted the edge of its load resulted in sling failure.

It is required that adequate synthetic sling protection devices be used to protect slings in any lift where the sling comes in direct contact with the edge or corner of its load. However, there are no consensus codes or standards stating the type, material, or purpose of the type of protective device used to protect the sling from being cut. Numerous industry standards and codes provide vague descriptions on how to protect synthetic slings. Without a clear, concise statement of how to protect synthetic slings, it is common for inadequate materials and sling protection devices to be used in an attempt to meet the intent of these requirements. The use of an inadequate sling protection device is the main cause of synthetic sling failure in all researched cases.

Commercial sling protection devices come in many shapes and sizes, and have a variety of names, as well as advertised uses. "Abrasion pads" and "wear protectors" are two different names for products with the same intended purpose. There is no distinguishable way to determine the extent of sling protection which these devices will provide, or what specific scenarios they are made for. This creates room for error in a field where error is unacceptable.

This report provides a recommended action for hoisting and rigging activities which require synthetic slings to contact a load, as well as recommended changes to industry standards which will benefit overall industry safety. 


\section{TABLE OF CONTENTS}

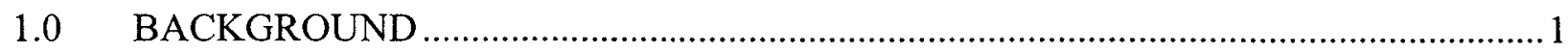

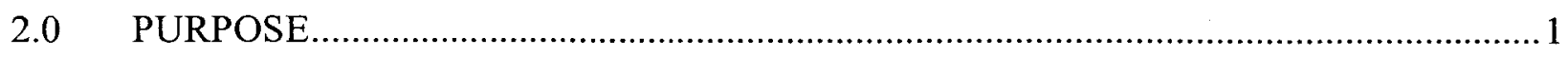

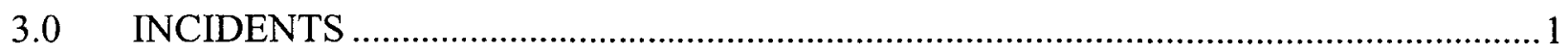

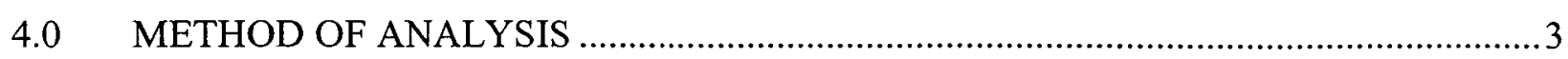

SUMMARY OF RESULTS ..............................................................................

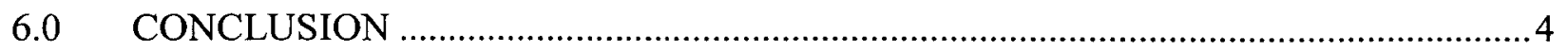

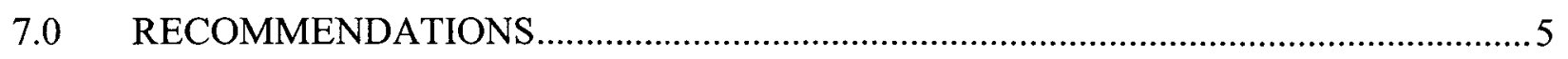

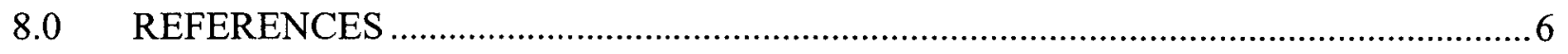

APPENDIX A - SLING FAILURE INCIDENTS AND ANALYSIS TABLE ......................... 7

APPENDIX B - NEW YORK CRANE ACCIDENT REPORT ....................................... 10

APPENDIX C - INCIDENT DESCRIPTIONS AND LESSONS LEARNED ........................13

APPENDIX D - DOE OPERATING EXPERIENCE SUMMARY .......................................22

APPENDIX E - DOE OPERATING EXPERIENCE SUMMARY …....................................28

APPENDIX F - INCIDENT DESCRIPTIONS AND LESSONS LEARNED ..........................31

APPENDIX G - NAVY CRANE CENTER TECHNICAL BULLETIN..................................34

APPENDIX H - INCIDENT DESCRIPTIONS AND LESSONS LEARNED ..........................38

APPENDIX I - SLINGMAX TECHNICAL BULLETIN AND DATA CHARTS ....................40 


\subsection{BACKGROUND}

It is common rigging practice to use crane slings in both basket and choker configurations. These rigging options can be used for a variety of sling types including synthetic, wire mesh, or wire rope, which are all used on an ordinary basis. However, when the object to be lifted contains an edge or corner, these configurations subject the sling to immense pressure at the points of contact between the edge and the sling. There have been numerous accidents which have occurred due to underestimating or overlooking this fact. Appendix A provides a table of 12 researched cases. In multiple cases, a synthetic sling was used over an edge with a sling protection device, and both the sling and protection failed.

Sling protection devices are available on the market, which are meant to protect both the sling and the load from being damaged. Almost all protection on the market is designed to prevent "scuffing" or "abrasion" due to friction. Protection comes in a variety of names including "softeners," "wear pads," and "abrasion protection." For clarity, these devices will be referred to as "sling protection devices."

\subsection{PURPOSE}

The purpose of this report is to provide information and a recommended action for any lift in which the sling comes in contact with the lifted load or an edge or corner. Failure of a sling and its protection device due to placement over an edge is a huge safety concern. One major point which must be stressed is that abrasion resistance and cut resistance are not the same thing. ASME B30.9-2006, section 4.1O.4d, states that "Slings in contact with edges, corners, protrusions, or abrasive surfaces shall be protected with a material of sufficient strength, thickness, and construction to prevent damage." Using an abrasion resistant protective device in an application where cut resistance is required would not meet the intent of this standard. If an abrasion resistant protective device is used for edge protection instead of a cut resistant device, there is a chance of both sling and protection failure.

\subsection{INCIDENTS}

The first incident studied occurred on March 15, 2008, and involved the collapse of a tower crane in Manhattan, New York (App. B). A company was hired to erect a tower crane on a high rise construction project. During a "jumping" process used to increase the height of the crane, the four slings which were being utilized to install the lateral support collar at the $18^{\text {th }}$ floor abruptly snapped. The catastrophic accident resulted in seven fatalities and extensive damage to the surrounding area. The contractor was accused of negligent rigging practices. He allegedly used four slings to support the collar when the manufacturer recommended that eight slings be used. The four slings, which were tied around the edges of the crane tower, were not protected with any sort of padding which caused severe cuts to the slings. On top of this, one of the slings 
had pre-existing damage to it and should not have been used. All three of these practices contributed to the accident.

In 2003, there was a tragic report of a foreman killed during installation of a conveyor belt counterweight (App. C). A crane was used to hoist 13,370 lbs. of steel plates which were to be used for the counterweight. The connecting rods failed to align with the holes in the support frame. The foreman was making an attempt to line the rods up when the slings carrying the load failed. He was struck by the plates and killed. No sling protection device was used to protect the slings from the edges of the plates. The slings failed due to cutting at the point where they contacted the edge of the plate.

On September 15, 2008, at the Hanford Solid Waste Facility, a waste cask was dropped about 4 inches due to failure of the synthetic slings (App. D). No protective padding was used to protect the slings from the edges of the cask. Luckily, there were no injuries, and the cask remained undamaged. Protective devices to protect the slings were not used because the lifted item was wrapped in plastic. Sling contact with the lifted item was not considered a hazard. The sling was cut by an edge of cask which was underneath the plastic.

In an incident at the National Renewable Energy Lab in February of 2005, a metal frame holding a forklift weighing 5,100 lbs. was dropped when the load shifted and an unprotected edge cut one of the slings (App. E). Once again, no protection was used on the edges in contact with the slings during the lift.

On November 4, 2008, a synthetic sling failure caused a 13,400 lb. steel plate to be dropped during construction of new laboratories at PNNL. (Ref 14). The unsettling thing about this case is that sling protection was used during the lift. Three of the pads were store bought. The fourth was a section of old synthetic sling, which is a common practice in industry. Unfortunately, these protection devices were inadequate to protect the sling from being sliced in half by the edges of the steel plate. In a follow up investigation of the incident, no specific criteria for the type of protection to be used with synthetic slings was found in any of the researched industry guides, lifting manuals, or regulatory citations.

On June 8, 2009, an 8,700 lb. piece of equipment was dropped at the Idaho National Laboratory (App. G). The cause of failure was, once again, a cut sling. Commercial sling protection, constructed of reinforced rubber, was used in three difference places on each of the two synthetic slings used during the lift. These protective devices, like a majority of protective devices on the market, were designed to prevent "scuffing" and "abrasion." They were completely useless in protecting the sling from the edges of the load, and both the protection and sling were sliced in two where they contacted the edge of the load.

In another similar case involving rubber "abrasive" protection, a girder was dropped during installation of a double girder bridge crane in 2007 (App. H). The protective devices used were designed to protect the sling and load from "chafing," and once again the exact same outcome was reached. The edges of the girder cut through both the sling and the rubber protection devices, and the load was dropped. 
In 2001 at Brookhaven National Laboratory, a Large Hadron Collider magnet was dropped 4.5 feet (App. E). Again, "anti-chafing" type protection was used when it was clear that anticutting protection was needed due to sharp edges. The inadequate sling protection devices failed along the edge of the magnet, the sling was cut, and the load crashed to the ground.

In October of 2004, a 65,000 lb. crane trolley was dropped during its replacement, and fell 4 feet (App. I). There were five protective devices used during the lift, and it is suspected that at least one was not placed correctly. The edge of the trolley support beam cut the sling and the trolley fell. The cause of this accident was due either to improper inspection of the lift configuration before the lift was made, inadequate protection of the sling by the protective devices, or both.

In an incident at the Idaho Reactor Technology Complex, a 5,400 lb. concrete ring fell while it was being unloaded from a truck (App. E). The synthetic slings used in the lift were arranged in a choker configuration, and old pieces of fire hose were used to protect them from the edges of the ring. The fire hose and slings were cut by the edges of the concrete ring, and the load was dropped.

A 26,000 lb. piece of equipment was dropped at Rocky Flats in Colorado during a test lift (App. E). Gloves were used for protection, and a raised metal edge on the equipment made short work of both the gloves and sling. The sling was cut, and the equipment fell to the ground.

\subsection{METHOD OF ANALYSIS}

After performing research on various brands of commercial sling protection devices, it was discovered that a majority of companies do not offer protection which is designed to be cut resistant. There are four major manufacturers of sling protective devices. Of these, only one company offers protection specifically designed to prevent the sling from being cut, along with testing information and a maximum rated load for which the sling protection would work. The other companies merely provided images of their products, and stated that they worked for wear and abrasion protection.

Many sling protection devices provided basically the same type of protection. The product offers sew on and/or Velcro wrap around type protection made of various materials which are designed to reduce and prevent damage to the sling incurred by "abrasion" and "general wear." The most common materials used in construction were typically nylon or leather. There was no guarantee on the effectiveness of protection against either abrasion or cutting. Most offered the same warning: "Wear protection may not prevent cutting or other sling damage," and gave no information on the protection rating.

After speaking with engineering at multiple sling protection device manufacturers, it was concluded that the protection they sold was to be used to the maximum rating of the sling itself. Representatives from each company said that their protection was not rated, and the ultimate effectiveness could vary depending upon the lifting application. This leaves room for uncertainty which is unacceptable when a failed lift could prove life threatening to the workers involved. 
If using sling protection devices, ensure they are specifically designated to protect slings from being cut by the edges of a load. One company offers products are constructed using Dyneema ${ }^{\circledR}$ polyethylene fiber, a common material used in bullet proof armor, safety gloves, and cables and rope where strength and durability are crucial. This company gave test results for abrasion and cutting, as well as a maximum protection rating of $25,000 \mathrm{lbs}$. per inch of sling width for their ComerMax cut protection products.

\subsection{SUMMARY OF RESULTS}

Failure to use protective padding, as was witnessed in several of the described cases, does not comply with multiple regulations including ASME B30.9, 29 CFR 1910, and WAC 296-2429419. These codes/standards basically state the same requirement in regards to the use of protective padding during lifts: edges in contact with slings must be padded with material of sufficient strength to protect the sling.

This requirement that "materials of sufficient strength be used" is too broad and creates a huge problem. There is no way to determine if the padding selected for use is of sufficient strength to protect the sling unless some sort of information is provided, such as a sling protection load rating. A high majority of sling protection device manufacturers on the market do not supply information on the effectiveness of their products. Without this information, a blind decision is ultimately being made in hopes that the chosen protection will not fail.

Another issue which must be addressed is the inconsistent naming of protective devices. In various reports and marketing ads, sling protection devices are given a variety of names including wear pads, softeners, sling protectors, comer protectors, abrasion pads, chaffing gear, scuffpads, and wear sleeves. With such an assortment of names, it is impossible to select an appropriate cut resistant sling protection device.

There is no way to determine if an edge calls for the use of cut resistant sling protection device. Any edge has the potential of cutting a sling if the contact point between the edge and sling is subjected to enough pressure. The only circumstance which a synthetic sling would be safe from potential cutting would be a case in which the load is completely smooth and circular.

\subsection{CONCLUSION}

There is no requirement that sling protection devices be rated, or built to any specifications. In order to improve industry safety, this must be change. Too many accidents have occurred because "abrasion resistant" protection devices were used in cases which required "cut resistant" protection devices. There is no way to distinguish how sharp an edge must be in order to call for a cut resistant protection device instead of abrasion resistant protection device. A requirement must be made that all sling protection devices be cut resistant, and that a protection load rating on this cut resistance must be supplied by the manufacturer. The use of random material should 
be prohibited, and only approved cut resistant protection devices should be used in any lifting application. This will eliminate any confusion on the question of what type of protection should be used in what scenario. If these measures are taken, safe and successful lifts can be made with $100 \%$ certainty that a synthetic sling failure will not occur due to inadequate protection of the sling.

The industry must also conform to one general name when referencing sling protection devices. There are too many variable names which are used regularly and create confusion. "Chaffing gear," "softeners," "scuffpads," and "wear pads" could all have different meanings to different people. A common industry name must be established in order to eliminate any potential confusion, so that everyone involved in a project or lift are on the same page.

The table provided (App. A) shows twelve fairly recent incidents involving sling failures. Six out of twelve of these accidents occurred due to inadequate sling protection which led to padding and sling failure. Three of the twelve accidents occurred because of failure to use sling protection. This problem must be addressed, and appropriate measures must be taken to ensure that slings stay protected from the possibility of being cut by a load.

\subsection{RECOMMENDATIONS}

Safety should be the number one priority in any hoisting and rigging application, and adequate measures should be taken to ensure the highest level of safety in all aspects. A requirement needs to be established to require the use of only approved cut resistant sling protection devices in all lifting applications. Industry standards need to be established that require sling protection devices to be cut resistant. The manufacturers must supply a clear protection load rating with their protective devices so they may be used safely. With a protection rating, a rigger will know exactly how heavy a load he can handle without slicing a sling. The sling protection should also be required to have a single, standard, unambiguous industry name in order to eliminate potential confusion when using sling protection devices.

Unless an alternate configuration may be used in which sling contact with the load or edge is avoided by the sling altogether, the recomm ended solution is to use cut protection, or any cut resistant sling protection device which specifies a sling protection load rating and is backed by testing and data. These protection devices should be used in all applications where the sling comes in contact with a load, unless the load is circular and has no edges. If these actions are taken, a lift can be made in confidence that there will not be a failure due to inadequately protected slings. 
RPP-RPT-42583, Rev. 0

\subsection{REFERENCES}

1. ASME B30.9-2006, Slings

2. ASME B30.26-2004, Rigging Hardware

3. DOE-STD-1190-2007, Hoisting and Rigging Standard

4. DOE-RL-92-36, Hanford site Hoisting and Rigging Manual

5. 29 CFR 1910, Occupational Safety and Health Standards

6. WAC 296-24-29419, Safe Operating Practices

7. www.iandisling.com

8. www.lni.wa.gov

9. www.dsm.com

10. www.lift-all.com

11. www.lift-in.com

12. www.caldwellinc.com

13. www.msha.gov

14. Pacific Northwest National Laboratory. "Critique Minutes/Notes," Event Number: SCPNSO-PNNL-PNNLBOPER-2008-0024. ATS \# 39419.1. 11/06/08. Phone: 1-888-3757665. 
RPP-RPT-42583, Rev. 0

APPENDIX A -

SLING FAILURE INCIDENTS AND ANALYSIS TABLE 
Sling Failure Incidents and Analysis

\begin{tabular}{|c|c|c|c|c|c|}
\hline Description of Accident & Cause of Accident & Fatalities/Damage & Sling Used & $\begin{array}{l}\text { Wear Pad } \\
\text { Used? }\end{array}$ & $\begin{array}{c}\text { Sling/Pad } \\
\text { Failure? }\end{array}$ \\
\hline $\begin{array}{l}\text { Appendix B (P.12) 3/15/2008 - } \\
\text { During a jumping process, a crane } \\
\text { being installed by Rapetti Rigging } \\
\text { Services in New York City collapsed } \\
\text { when slings holding up a lateral } \\
\text { support collar snapped. The } \\
\text { accident resulted in multiple } \\
\text { fatalities. }\end{array}$ & $\begin{array}{l}\text { Negligent rigging practice. } \\
\text { There were no softeners } \\
\text { used to protect the slings } \\
\text { from the edges of the crane } \\
\text { tower. Pre-lift inspection } \\
\text { failed to recognize one of } \\
\text { the slings was also } \\
\text { damaged before use. }\end{array}$ & $\begin{array}{l}7 \text { deaths resulted. } \\
6 \text { workers and } 1 \\
\text { tourist were killed. }\end{array}$ & $\begin{array}{l}4 \text { polyester } \\
\text { slings were } \\
\text { used. }\end{array}$ & No & Yes \\
\hline $\begin{array}{l}\text { Appendix C (p.15) 3/24/2003 - } \\
\text { A surface foreman was killed during } \\
\text { installation of a conveyor belt } \\
\text { counterweight weighing } 13,370 \mathrm{lbs} \text {. } \\
\text { The steel plates that were to be } \\
\text { used as the counterweights fell and } \\
\text { struck the foreman when the nylon } \\
\text { slings failed. }\end{array}$ & $\begin{array}{l}\text { The slings used were not } \\
\text { properly protected from the } \\
\text { sharp edge of the steel } \\
\text { plates being lifted and failed } \\
\text { when they were cut by the } \\
\text { edge. }\end{array}$ & $\begin{array}{l}1 \text { death resulted } \\
\text { when the foreman } \\
\text { was struck by the } \\
\text { plates. }\end{array}$ & $\begin{array}{l}2 \text { nylon slings } \\
\text { rated at } 12,800 \\
\text { lbs. were used } \\
\text { in a basket } \\
\text { hitch. }\end{array}$ & No & Yes \\
\hline $\begin{array}{l}\text { Appendix D (p.24) 9/15/2008 - } \\
\text { A retrieved waste cask was being } \\
\text { lifted at the Hanford Solid Waste } \\
\text { Facility when one of the slings } \\
\text { broke. The cask dropped } 4 \text { inches } \\
\text { to the ground, but was not } \\
\text { damaged. }\end{array}$ & $\begin{array}{l}\text { The slings selected were } \\
\text { inappropriate for the rigging } \\
\text { configuration and no } \\
\text { softener pads were used. }\end{array}$ & $\begin{array}{l}\text { No injury or } \\
\text { damage. }\end{array}$ & \begin{tabular}{|l|} 
Synthetic slings \\
used in a \\
choker hitch.
\end{tabular} & No & Yes \\
\hline $\begin{array}{l}\text { Appendix E (p.30) 2/17/2005 - } \\
\text { A trail lift of a metal frame holding a } \\
\text { forklift weighting } 5,100 \mathrm{lbs} \text {. was } \\
\text { dropped at the National Renewable } \\
\text { Energy Lab when the load shifted } \\
\text { and an unprotected edge cut one of } \\
\text { the slings. }\end{array}$ & $\begin{array}{l}\text { The root cause was failure } \\
\text { to protect the sling from the } \\
\text { rough edge of the frame. }\end{array}$ & $\begin{array}{l}\text { No injury or } \\
\text { damage. }\end{array}$ & $\begin{array}{l}\text { Multiple slings } \\
\text { were used. } \\
\text { Only one sling } \\
\text { failed. }\end{array}$ & No & Yes \\
\hline $\begin{array}{l}\text { Appendix F (p.36) } 6 / 8 / 2009 \text { - } \\
\text { Maintenance personnel were off- } \\
\text { loading equipment from a truck bed } \\
\text { with an overhead crane. One of the } \\
\text { two slings in a basket configuration } \\
\text { failed, and one side of the } 8700 \mathrm{lb} \text {. } \\
\text { load dropped to the bed. }\end{array}$ & $\begin{array}{l}\text { An adequate evaluation of } \\
\text { wear protection } \\
\text { requirements was not done. } \\
\text { The wear pads and sling } \\
\text { used both failed. }\end{array}$ & $\begin{array}{l}\text { No injury or } \\
\text { damage. }\end{array}$ & $\begin{array}{l}2 \text { synthetic web } \\
\text { slings rated at } \\
10,000 \mathrm{lb} \text {. each } \\
\text { were used in a } \\
\text { choker hitch. }\end{array}$ & Yes & Yes \\
\hline $\begin{array}{l}\text { Appendix G (p.39) } 2007 \text { - } \\
\text { During installation of a double girder } \\
\text { bridge crane, a girder was dropped } \\
\text { after one of the two polyester slings } \\
\text { failed. }\end{array}$ & $\begin{array}{l}\text { The slings failed due to } \\
\text { inadequate protection of the } \\
\text { sling from the sharp edges } \\
\text { of the girder. }\end{array}$ & $\begin{array}{l}\text { No injury or } \\
\text { damage }\end{array}$ & $\begin{array}{l}2 \text { polyester } \\
\text { slings each } \\
\text { with a rated } \\
\text { capacity of } \\
17,000 \text { lbs. }\end{array}$ & Yes & Yes \\
\hline
\end{tabular}




\section{Sling Failure Incidents and Analysis}

\begin{tabular}{|c|c|c|c|c|c|}
\hline Description of Accident & Cause of Accident & Fatalities/Damage & Sling Used & $\begin{array}{c}\text { Wear Pad } \\
\text { Used? }\end{array}$ & $\begin{array}{l}\text { Sling/Pad } \\
\text { Failure? }\end{array}$ \\
\hline $\begin{array}{l}\text { Appendix E (p.30) 8/29/2001 - } \\
\text { A Large Hadron Collider magnet } \\
\text { was dropped } 4.5 \text { feet at the } \\
\text { Brookhaven National Laboratory } \\
\text { when one of the slings was cut. }\end{array}$ & $\begin{array}{l}\text { Inadequate protection was } \\
\text { used to protect the slings } \\
\text { from the sharp edges of the } \\
\text { magnet. }\end{array}$ & $\begin{array}{l}\text { No injury or } \\
\text { damage. }\end{array}$ & $\begin{array}{l}2 \text { synthetic } \\
\text { slings were } \\
\text { used. Only } \\
\text { one was cut. }\end{array}$ & Yes & Yes \\
\hline $\begin{array}{l}\text { Appendix H (p.42) 10/24/2004 - } \\
\text { During replacement of a } 65,000 \mathrm{lb} \text {. } \\
\text { crane trolley, a synthetic sling failed } \\
\text { and one end of the trolley dropped } \\
\text { four feet to the floor. There were no } \\
\text { injuries, but the concrete floor was } \\
\text { shattered. }\end{array}$ & $\begin{array}{l}\text { Wear pads were improperly } \\
\text { installed and at least } 1 \text { pad } \\
\text { was not in position to } \\
\text { protect the sling. The edge } \\
\text { of the trolley support beam } \\
\text { cut the sling and the trolley } \\
\text { fell. }\end{array}$ & $\begin{array}{l}\text { No injury. The } \\
\text { concrete floor was } \\
\text { shattered and a } \\
\text { structural analysis } \\
\text { was conducted. }\end{array}$ & $\begin{array}{l}3 \text { synthetic } \\
\text { slings were } \\
\text { used. }\end{array}$ & Yes & Yes \\
\hline $\begin{array}{l}\text { Appendix E (p.30) 7/11/2005 - } \\
\text { A 5,400 lb. concrete ring was } \\
\text { dropped at the Idaho Reactor } \\
\text { Technology Complex while it was } \\
\text { being unloaded from a truck. }\end{array}$ & $\begin{array}{l}\text { A sharp inner edge on the } \\
\text { ring cut through the padding } \\
\text { and one of the slings. This } \\
\text { caused the second sling to } \\
\text { also fail. }\end{array}$ & $\begin{array}{l}\text { No injury or } \\
\text { damage. }\end{array}$ & $\begin{array}{l}2 \text { synthetic } \\
\text { slings } 20 \text { feet in } \\
\text { length were } \\
\text { used in a } \\
\text { choker hitch. }\end{array}$ & Yes & Yes \\
\hline $\begin{array}{l}\text { Appendix E (p.30) 8/30/2002 - } \\
\text { A } 26,000 \mathrm{lb} \text {. piece of equipment } \\
\text { dropped } 6 \text { inches at Rocky Flats } \\
\text { when a test lift was being } \\
\text { performed. }\end{array}$ & \begin{tabular}{|l|} 
The weight of the \\
equipment was \\
underestimated and the \\
padding used to protect the \\
sling from a raised metal \\
ridge was inadequate.
\end{tabular} & $\begin{array}{l}\text { No injury or } \\
\text { damage. }\end{array}$ & No. info. & Yes & Yes \\
\hline $\begin{array}{l}\text { Appendix D (p.24) 9/24/2008 - } \\
\text { An overloaded synthetic sling failed } \\
\text { at the Waste Isolation Pilot Plant } \\
\text { and struck a technician while trying } \\
\text { to load an empty shipping cask onto } \\
\text { a trailer. }\end{array}$ & $\begin{array}{l}\text { The load was torque down } \\
\text { during installation. The } \\
\text { operator accidently tried to } \\
\text { lift the load instead of } \\
\text { lowering it which lifted the } \\
\text { load and the truck trailer } \\
\text { and caused one of the two } \\
\text { synthetic slings to snap. }\end{array}$ & $\begin{array}{l}\text { Technician } \\
\text { received minor } \\
\text { injury from being } \\
\text { shipped by the } \\
\text { sling. }\end{array}$ & $\begin{array}{l}2 \text { synthetic } \\
\text { slings each } \\
\text { rated at } 3,200 \\
\text { lbs. }\end{array}$ & $\mathrm{N} / \mathrm{A}$ & Yes \\
\hline $\begin{array}{l}\text { Appendix D (p.24) 8/19/2008 - } \\
\text { A 6,000 lb. shield window liner fell } 3 \\
\text { feet after two lifting eye nut } \\
\text { assemblies sheared off from the top } \\
\text { of the liner due to side loading } \\
\text { stresses. }\end{array}$ & $\begin{array}{l}\text { Drawings/specification } \\
\text { lacked the correct rigging } \\
\text { configurations. Eye bolt } \\
\text { shoulder was not flush } \\
\text { against the liner reducing } \\
\text { the overall strength. }\end{array}$ & $\begin{array}{l}\text { No injury or } \\
\text { damage. }\end{array}$ & $\begin{array}{l}\text { Eye bolts were } \\
\text { used along with } \\
\text { a } 3,000 \mathrm{lb} \text {. } \\
\text { rated chain } \\
\text { hoist. }\end{array}$ & N/A & Yes \\
\hline
\end{tabular}


RPP-RPT-42583, Rev. 0

APPENDIX B -

NEW YORK CRANE ACCIDENT REPORT

District Attorney-New York District. News Release. January 5, 2009. http://manhattanda.org/whatsnew/press/2009-01-05.shtml 
NEWS RELEASE

January 5, 2009
Contact: Alicia Maxey Greene

212-335-9400

Manhattan District Attorney Robert M. Morgenthau announced today the indictment of a tower crane rigger and his company on homicide and related charges in the crane collapse on March 15, 2008, that caused the deaths of seven people.

WILLIAM RAPETTI, 48, and RAPETTI RIGGING SERVICES INC. have been indicted on multiple charges of manslaughter, criminally negligent homicide, assault, reckless endangerment and failure to file tax returns.

The investigation leading to today's indictment revealed that RAPETTI, a tower crane rigger licensed by the New York City Department of Buildings, and his rigging company, RAPETTI RIGGING SERVICES, were hired to erect the tower crane at a high-rise construction site at 303 East $51^{\text {st }}$ Street in Manhattan. According to the New York City Building Code, only licensed riggers are permitted to oversee this type of work and they must be present at the job site whenever erection and dismantling occurs.

On March 15, 2008, RAPETTI and a rigging crew working under his supervision installed several additional sections to the mast of the tower to increase the height of the crane, in a process known as "jumping." The crew consisted of RAPETI, who was directing operations from the $18^{\text {th }}$ floor of the building, crane operator Wayne Bleidner, crane oiler Anthony Mazza, as well as Brad Cohen, Clifford Canzona, John Della Porta, Santino Gallone, and Aaron Stephens.

As part of the jumping process, the crew had to install a steel "collar" around the mast of the crane and connect it to the $18^{\text {th }}$ floor with steel tie-beams for lateral support. While the collar is being connected to the tie-beams, it must temporarily be suspended from the crane mast with "slings" - polyester straps with loops at each end that attach to both the mast and the collar. However, during the collar and beam installation that day, the four slings being used abruptly snapped, causing the collar to slide down the tower. The collar, which weighed approximately 12,000 pounds, slid down the mast and crashed into collar at the $9^{\text {th }}$ floor with sufficient force to dislodge it. The two collars then slid further down the mast and crashed into the third floor collar, dislodging that one as well, leaving the crane completely unsupported.

The impact of the three collars violently jostled the base of the crane and caused the entire crane to tip over and collapse against the roof of an apartment building across the street on the south side of $51^{\text {st }}$ Street. The top of the crane, including the cab and boom, broke away from the lower sections and catapulted over the apartment building and landed farther to the south, completely demolishing a townhouse on East $50^{\text {th }}$ Street. Crane operator Bleidner and rigging crew members Canzona, Cohen, Gallone, Mazza, and Stephens died in the collapse. Odin Torres, an occupant of the townhouse demolished in the collapse, was also killed. Crew member Della Porta was seriously injured, as were John Gallego and Juan Perez, two other occupants of the townhouse.

The investigation revealed that RAPETTI's reckless and negligent rigging practices caused the failure of the slings and the collapse of the crane. RAPETTI violated numerous provisions of the New York City Building Code, federal regulations, industry standards and the manufacturer's specifications pertaining to the proper use of the polyester slings. In particular, one of the failed slings had substantial pre-existing damage, including cuts and severe discoloration that would have been obvious to RAPETTI and he properly inspected 
the sling as mandated by the Building Code, federal regulations, and industry standards. Because the preexisting damage had substantially diminished the capacity of that sling, it should not have been used at all.

In addition, all four slings had been tied to the crane in a knot called a "choke," which has the weakest loadbearing capacity of the three standard knots used in this type of operation. The slings were also tied around sharp metal edges of the crane tower without any kind of protective padding, which was also a violation of the Building Code, federal regulations, industry standards and warning labels on the slings themselves. The use of the slings without protective padding caused severe cuts to the slings, greatly reducing their capacity and ultimately leading to their failure. Finally, the investigation revealed that RAPETTI failed to follow the crane manufacturer's specifications that the collar should have been supported by eight slings, not four.

During the course of the investigation into the crane collapse, an examination of the financial records of RAPETTI RIGGING SERVICES INC. revealed that the company did not file a corporate income tax return in New York City for the tax years 2006 and 2007, in violation of the New York City Administrative Code.

RAPETTI and RAPETTI RIGGING SERVICES INC., are charged with seven counts of Manslaughter in the Second Degree, a class $C$ felony, which is punishable by up to 15 years in state prison, seven counts of Criminally Negligent Homicide, a class $E$ felony, which is punishable by up to 4 years in prison; three counts of Assault in the Second Degree, a class D felony, which is punishable by up to 7 years in prison; one count of Reckless Endangerment in the Second Degree, a class A misdemeanor, which is punishable by up to one year in jail; and two counts of Failure to File a Return or Report, in violation of the New Your City Administrative Code, an unclassified misdemeanor, which is punishable by up to one year in jail and a fine up to $\$ 20,000$.

The defendants are scheduled to be arraigned today in Part 1 of New York State Supreme Court.

Mr. Morgenthau thanked New York City Department of Investigation Commissioner Rose Gill Hearn, Assistant Commissioner John Kantor, Inspector General Michael Carroll and Assistant Inspector General Edward Zinser, and Occupational Safety and Health Administration Manhattan Area Office Director Richard Mendelson.

Assistant District Attorneys Sean Sullivan, Carey Ng and Deborah Hickey, all of whom are assigned to the Rackets Bureau, are handling the prosecution of this case under the supervision of Eric Seidel, Chief of the Rackets Bureau and Patrick J. Dugan, Chief of the Investigation Division. Investigators Jack Patterson and Jonathan Savel also worked on the investigation, under the supervision of Investigation Bureau Chief Joseph Pennisl. Paralegals Michael Morris and Aaron Teitelbaum also assisted.

Defendents' Information:

WILLIAM RAPETTI, 9/6/1960

129 Atlantic Avenue

Massapequa Park, New York

RAPETTI RIGGING SERVICES, INC.

129 Atlantic Avenue

Massapaqua Park, New York

http://manhattanda.org/whatsnew/press/2009-01-05.shtml

$6 / 22 / 2009$ 
RPP-RPT-42583, Rev. 0

\section{APPENDIX C - INCIDENT DESCRIPTIONS AND LESSONS LEARNED}

United States Department of Labor, Mine Safety and Health Administration: Metal and Nonmetal Mine Safety and Health. "Report of Investigation:

Underground Nonmetal Mine (Limestone) Fatal Machinery Accident, March 24, 2003."

http://www.msha.gov/FATALS/2003/ft103m05.pdf 


\section{OVERVIEW}

On March 24, 2003, James G. Carey, surface foreman, age 46, was fatally injured when he was struck by a conveyor belt counterweight that was being installed. A crane was lifting steel plates that were to be used as the counterweights. The victim was positioning the plates when the rigging failed and the plates crushed him.

The accident occurred because the procedures used to install the counterweight were inadequate. When the connecting rod failed to align with the holes in the support frame cross-member, the victim positioned himself under the suspended counterweight to drive the rod into position. The nylon rigging straps, used to lift the steel counterweight, became damaged on the strap edges of the plates. The damaged rigging then failed and the counterweight fell.

\section{GENERAL INFORMATION}

JS\&G Underground Mine \#1, a limestone operation owned and operated by Joliet Sand \& Gravel Company, was located in Joliet, Will County, Illinois. The principal operating officials were George Comerford, Jr., president; and Robert Archibald, vice president. The mine was normally operated three, 8 -hour shifts, six days a week. Total mine employment was 28 persons.

Limestone was mined underground using the room and pillar method. Headings were drilled, blasted, and loaded into haul trucks with front-end loaders. The trucks hauled the rock to the primary crusher underground. The crushed rock was conveyed to surface via the decline conveyor belt and further processed at the mill, where it was sized, stockpiled and sold for construction aggregate.

The last regular inspection at this operation was completed February6, 2003. Another inspection was conducted following this investigation.

\section{DESCRIPTION OF THE ACCIDENT}

On the day of the accident, James G. Carey, surface foreman (victim), reported for work at 7:00 am, his normal starting time. Michael H. Campbell, crane operator; Kevin Appleton, maintenance; and William Ferguson, maintenance; were the surface crew and Carey was their supervisor.

The surface crew went about normal maintenance duties until lunchtime, when they learned that a belt splicing crew had finished splicing the decline conveyor belt. After finishing their lunch, the surface crew traveled to the area of the decline conveyor belt take-up pulley to install a new counterweight system.

The crew arrived at the decline conveyor take-up system and started assembling the counterweight on top of two concrete blocks that were positioned directly under the take-up 
pulley. The counterweight consisted of 14 steel plates designed to be held together and attached to the take-up pulley with three threaded steel rods.

Carey calculated the load and selected two nylon web straps to attach to the plates. The straps were 12 feet long, 2 inches wide, and were rated for 12,800 pounds each in a basket configuration, which was used. Reportedly the straps were new and were removed from their packaging and Carey positioned them around the plates. The straps were then attached to chains, already in place, which in turn attached to steel cable slings hung from a crane. Carey then directed Campbell to lift the load. After several attempts to line up the three bolts with their respective holes in the take-up pulley frame, Carey directed Campbell to lower the counterweight on the concrete blocks. Carey then repositioned the straps. One of the end bolts was removed and the other had dropped out. It was thought that it would be easier to thread the center bolt, attach the nut, then install the other two bolts. The crane operator was again directed to raise the weight.

As the counterweight plates were lifted into position, Appleton, who was working from a manlift basket above the take-up pulley frame, was to install the nuts. When the hanger bolt would not go through the frame, Carey moved underneath the counterweight and used a sledgehammer to drive the bolt through. During this activity, the nylon slings failed and the counterweight struck Carey.

Campbell, Ferguson, and Appleton ran to aid Carey and 911 was called. Emergency personnel arrived and, because of the massive head trauma, they called the county coroner who arrived and pronounced the victim dead at 5:29 p.m.

\section{INVESTIGATION OF THE ACCIDENT}

MSHA was notified of the accident at 6:05 p.m. on March 24, 2003, by a telephone call from Dan Foltywienwicz, risk manager, to Steven Richetta, assistant district manager. An investigation was started the next day. An order was issued pursuant to section $103(\mathrm{k})$ of the mine act to ensure the safety of miners.

An MSHA accident investigation team conducted a physical inspection of the accident scene, interviewed employees, and reviewed conditions and work procedures relevant to the accident. MSHA conducted the investigation with the assistance of mine management and employees.

\section{DISCUSSION}

\section{Decline Conveyor}

Crushed limestone of minus 10 -inch size was conveyed from the primary crusher underground to the surface by a series of conveyor belts. Sequentially, the material left the crusher on a short belt that dumped onto the transfer conveyor belt. At the end of the transfer belt, the material dumped onto a decline conveyor belt. The 1,100-foot-long decline conveyor belt transported the 
crushed limestone upgrade from the mine into the quarry pit to a transfer point, where it then dropped through a chute onto a stacker conveyor belt. The material was conveyed further upgrade and was then dumped onto a surge pile. The accident occurred on the surface at the head end of the decline conveyor belt beneath the take-up pulley counterweight frame. The frame was approximately 12 feet north of the belt drive pulley.

The decline conveyor belt was manufactured by American Bin and Conveyor, Incorporated. It was Model No. 48X1021, and had Serial No. 02-001. This belt was first used on November 22, 2002, and was last used on December 20, 2002. Its total usage was 222 hours prior to the accident. The 48-inch wide belt was supported by a steel truss structure that was 44 inches deep and 60 inches wide. It consisted of angle-shaped members that made up the bottom chords, and diagonals. The top and bottom chord angles were 3 -unch by 4 -inch by $1 / 4$-inch. The diagonal angles were 2 -inch by 2 -inch by $1 / 4$-inch.

Due to operational problems with the decline conveyor, the company consulted with the manufacturer and determined that the problems could be remedied by replacing the original dual counterweight system with a single unit system. The Manufacturer agreed to provide a new retrofit counterweight frame, mounts, and a guide system. Joliet Sand \& Gravel was responsible for installing the new system and for providing the steel plates and rods, which would serve as the counterweight. In the week prior to the accident, the belt was cut; the original counterweight was removed; and the new mounts, guide tubes, and frame were installed. The belt was fed through the new counterweight frame, which at the time did not include the stack of 14 plates. To provide a method of tensioning the newly shortened belt, a small angle was temporarily welded to each circular guide tube to act as stoppers. On the day of the accident, the empty takeup frame was lifted up against the guide stoppers while the contractors spliced the shortened belt. The accident occurred when the mine workers were attempting to attach the stack of plates to the new elevated counterweight frame.

The counterweight was composed of 14, one-inch-thick, ASTM A36 steel plates. The plates measured 46-3/4 inches wide by 72 inches long and weighed 955 pounds each. The combined stack weight was 13,370 pounds. There were three, 1-5/8 inch diameter holes in each plate, through which three threaded rods were to be used to connect the stacked plates to the counterweight frame. The holes were aligned along the centerline of the plate, which was parallel to the plate's long dimension. The center of the middle hole was 36 inches from the edge of the plate, and the center of each outer hole was 4-1/8 inches from the edge of the plate. The bolts that were to be used to attach the weights to the counterweight frame were $1-1 / 2$ inch diameter, 36-inch-long all-thread rods. The nuts were $2-3 / 8$ inches by $1-1 / 2$ inches.

The plates were manufactured by Northern Illinois Steel Supply Company. According to the manufacturer, each plate was cut to size with a machine mounted cutting torch. A 4-1/2 inch diameter grinder wheel was then used to remove any slag or rough spots. The plate edges were at 90-degree angles to each other. There were no special provisions with this job to radius any of the plate corners.

The take-up pulley was mounted to the center of a rectangular frame that measured 81-3/4 inches wide and 52 inches high. The counterweight frame consisted of rectangular tube-shaped 7-inch 
by 5 -inch by $3 / 8$-inch top and bottom cross members and 5 -inch by 5 -inch by $3 / 8$-inch vertical members, which fit over the 3-1/2-inch diameter circular slide tubes. The bottom cross member was predrilled with three holes for attaching the three threaded rods. Predrilled plates measuring 8 -inches by 5 -inches by $1 / 2$-inch were welded at the three hole locations along the bottom cross member.

\section{Rigging}

The bottom cross member of the counterweight frame was measured to be 96 inches from the ground. Two concrete blocks, 2 -feet by 2 -feet by 6 -feet were stacked between the counterweight guide tubes. The steel plates were then stacked one at a time on top of the 48-inch high block platform prior to lifting them as a whole. Therefore, the 14-inch high stack of plates needed to be lifted approximately 34 inches in order to be bolted to the bottom cross member of the counterweight frame.

A P\&H Model R-150 crane, Serial No. 33146, was used to lift the counterweight. It had an extending boom ranging in length from 24 feet to 60 feet and a maximum lifting capacity of 15 tons. The crane was positioned along the west side of the conveyor with its outriggers fully extended. The left front (northeast) outrigger was resting on two steel bearing plates to spread the load into a soft muddy area on the ground. For this lift, the crane's operating radius was 24$1 / 2$ feet. According to the load chart posted on the crane, at this operating radius it had a capacity of 15,500 pounds. This capacity was limited by the stability of the crane against tipping; not its structural competence. The crane was not equipped with a load indicating gauge.

Reportedly, the hoisting equipment consisted of a combination of wire ropes, chains, and synthetic nylon slings. Starting from the tip of the crane boom, a four part line was connected to the crane block. A 5-inch by 10-inch master link from a four-leg wire rope bridle was looped over the crane hook. The four wire ropes were $5 / 8$ inches in diameter and were 20 feet long. The hooks located at the end of each wire rope had a 10,000-pound working load limit. Two of the four wire ropes were strung down through the conveyor truss structure, while the other two wire ropes wrapped back up and were hooked onto the master link. With two wire ropes, the rated capacity was approximately 14,000 pounds. Two metal chains were then draped over the wire rope end hooks that hung down through the conveyor truss structure. The chains hung down around the take-up pulley, which was mounted to the counterweight frame. Each chain, which was made by ACCO, measured 16 feet long and had a 7,100-pound working load limit. In a basket lift configuration, similar to how it was draped over the wire rope hook, each chain had a capacity of 14,200 pounds. Finally, two nylon slings were wrapped around the counterweight plates in a basket configuration and attached to each chain hook.

Based on rub markings on the take-up pulley and on a diagonal (angle-shaped) brace in the top chord of the truss, it did not appear that it was a straight vertical pick up through the counterweight frame and truss. In addition, the boom tip of the crane was positioned approximately 1 foot to the west of the centerline of the conveyor belt. This off-center alignment and interface may have caused a slightly unbalanced load to be applied to one of the nylon slings. 


\section{Accident Scene}

Kevin Appleton was assigned to work from a man lift basket platform. The man lift was a JLG Model $60 \mathrm{H}$, with a 60 -foot maximum reach and a 36-inch x 96-inch platform. Appleton's assignment was to place the nuts onto the threaded rods once they were fed up through the stack of plates and the lower counterweight frame cross member. Appleton was in the basket, which was positioned to the south of the counterweight frame, when the accident occurred.

The counterweight was lifted and suspended for at least 30 minutes while the victim attempted to feed the bolts up through the holes in the counterweight frame cross member. The steel plates were suspended in the air approximately 2 inches from the bottom of the cross member. The victim was under the counterweight using a sledgehammer to help drive the center bolt through the holes in the lower cross member, when the nylon slings suddenly failed. One end of the counterweight landed on the concrete blocks while the other end rested on the ground.

According to a witness statement and the final position of the blocks, it appears that the west side nylon strap failed first.

During the recovery of the victim's body, the counterweight was moved and set entirely on the ground. The concrete blocks were also knocked over on their sides. The center bolt was found to be protruding approximately 17-1/2 inches from the top steel plate. The bolt was bent at a point about 3 inches from the top plate. The bottom 2 inches of the center bolt had been torched off and only one nut had been installed.

The top 6-3/4 inches of the threads on the center bolt were stripped when the plate stack fell. This dimension agreed exactly with the length of the threaded rod that would have penetrated the bottom tube of the counterweight frame. The distance from the lower outside face of the bottom tube to the inside face of the top of the bottom rectangular tube was 6-3/4 inches. The shiny mark may have been caused by the victim hammering on the bolt to get it fed through the upper hole, and/or it could have been caused by the crane placing upward lift pressure on the plates. If the protruding bolt was being pinched by the relative alignment of the various plates in the stack, it could have transmitted upward lift force to the tip of the bolt and ultimately to the bottom rectangular tube.

\section{Nylon Sling Evaluation}

The two failed nylon straps were taken from the scene by the Will County Sheriff's Department. The custody of the slings was then transferred to MSHA for further evaluation on April 2, 2003. (See photograph of slings in Appendix C.)

One nylon sling was used to suspend the east side of the plates and the other strap was used to hold up the west side. The two pieces of the east side sling were referred to as the north and south pieces, respectively. The north piece was 70 inches long from the end of the eye loop to the break location. The break would have corresponded with the lower north corner of the basket configuration. The south piece was 75 inches long from the end of the eye loop to the break location. Approximately 32 inches from the eye loop of the south piece there was a distinct abrasion area on the sling that appeared to be partly cut. This would have corresponded 
to the south corner of the basket configuration. Likewise, evidence of yellow abraded nylon sling fibers was found adhering to the lower south edge of the east side of the stack of plates.

The two pieces of the west side sling were also referred to as the north and south pieces, respectively. The north piece was 63-1/4 inches long from the end of the eye loop to the break location. The break corresponded with the contact location of the lower north corner of the basket configuration. The south piece was 82-1/2 inches long from the end of the eye loop to the break location. Approximately 40-1/2 inches from the eye loop on the south piece, there was a distinct abrasion area on the sling where it had started to be cut. This would have corresponded to the south corner of the basket configuration.

On April 23, 2003, an identical sling from the same manufacturer was tested at Safety Sling in Pittsburgh, Pennsylvania. The tension load to break the sling was nearly 32,000 pounds. This was at the expected factor of safety for a sling of this width. A direct pull test showed that a failure from tension overload is clearly different than the type of relatively abrupt tears that occurred when the slings were used around unprotected sharp plate corners on the day of the accident. The failure surface of the tested sling had no distinct edge and had considerably more fraying than the accident slings.

\section{Training and Experience}

The victim had 8 years mining experience, all at this mine. He had received training in accordance with 30 CFR, Part 48.

\section{ROOT CAUSE ANALYSIS}

Causal Factor - The nylon straps used to lift the steel plates were not protected from the sharp metal edges of the steel.

Corrective Action - Always refer to manufacturer's recommendations, hazard alerts and warnings. The nylon straps had labels stamped with warning to protect straps from sharp edges and rough loads.

Causal Factor - The victim was working under a suspended load.

Corrective Action - Procedures should be established to ensure suspended loads are properly supported prior to persons working under them. Management should review their safety program and implement a job task analysis before maintenance work is performed.

Causal Factor - The conveyor belt was spliced together before the counterweight was installed.

Corrective Action - Review tasks that are performed infrequently to identify hazards that may result from work action sequence interruption. The counterweight installation should have been completed before the belt was spliced together. Design changes need to incorporate a safety review to insure such changes do not pose any unforeseen hazards. A job task analysis should be 
developed to detect hazards and establish safe work procedures before performing maintenance or repair work.

\section{CONCLUSION}

With respect to total load weight of 13,370 pounds, it does not appear that either the crane or the rigging was used beyond their design capacity. However, the nylon slings were not used in accordance with the conditions indicated on the manufacturer's tag. The sharp edge corners of the counterweight plates cut through the west side sling first, instantly transferring the load to the east side sling and the frictional interface between the threaded rod and the bottom tube of the counterweight frame, neither of which could support the remaining load. The threaded rod bent and pulled out and the east side strap simultaneously broke, allowing the weights to fall on the victim. The additional force caused by trying to lift the weight stack and feed its protruding bolt through the hole may have contributed to the cutting of the slings.

A task analysis had not been conducted to identify possible hazards and establish safe procedures to follow when installing the counterweight.

The difficulty posed by attempting to align and secure the counterweight ends was unexpected and resulted in the victim positioning himself under the suspended load to drive the connecting rod into position. Failure to protect the nylon straps from damage caused by the edges of the steel plates contributed to the accident cause.

\section{ENFORCEMENT ACTIONS}

Order No. 6142021 was issued on March 25, 2003, under Section 103 (k) of the Mine Act:

A fatal accident occurred at this operation on March 24, 2003, when a miner was attempting to secure a hoisted gravity take-up pulley weight. This order is issued to assure the safety of persons at this operation and prohibits any work around the decline conveyor gravity take-up and P\&H 15 ton crane, until MSHA determines that it is safe to resume normal operations as determined by an authorized representative of the Secretary of Labor. The mine operator shall obtain approval from an authorized representative for all actions to recover and/or restore operations in the affected area.

This order was terminated on March 28, 2003, after the conditions that contributed to the accident no longer existed.

Citation No. 6155739 was issued on April 16, 2003, under Section 104 (d)(1) of the Mine Act for violation of 30 CFR 57.16009:

A fatal accident occurred on March 24, 2003, at this operation when a supervisor was struck by a conveyor belt counterweight that was being installed. The victim was positioned under the suspended counterweight using a hammer to guide a hanger bolt into 
position when the nylon rigging straps failed. Failure to establish a procedure to install the counterweight in a manner that would not require a miner to be positioned under the suspended load to align the attachment bolts constitute more than ordinary negligence and is an unwarrantable failure to comply with a mandatory standard.

This citation was terminated on June 26, 2003, after a mine operator devised a method to install the counterweight that ensured persons would be clear of suspended loads. All personnel were re-instructed to stay clear of suspended loads.

Citation No. 6155740 was issued on April 16, 2003, under Section 104(a) of the Mine Act for violation of $30 \mathrm{CFR} 57.16007 \mathrm{~b}$ :

A fatal accident occurred on March 24, 2003, at this operation when a supervisor was struck by a conveyor belt counterweight that was being installed. Nylon rigging straps had been used to support the load, which consisted of 14 rectangular plates of steel that weighed about 960 pounds each. The edges of the steel plates had sharp 90-degree angles, which bore on the nylon straps, causing them to fail. These unprotected nylon slings were not suitable for this load with sharp edges. Labels on the slings warned persons to "Avoid sharp edges or rough loads" and to "Protect webbing from sharp edges".

The citation was terminated on June 26, 2003, after the mine operator devised a method to install the counterweight that ensured the use of proper rigging. All personnel received rigging safety training on April 22, 2003 from a manufacturer of industrial rigging.

Approved by:

Felix A. Quintana

District Manager

North Central District
Date: 
RPP-RPT-42583, Rev. 0

\section{APPENDIX D - DOE OPERATING EXPERIENCE SUMMARY}

DOE, Operating Experience Summary, Issue Number 2008-10, Article 1:

"Three Recent Events Involved Failed Rigging and Lifting Hardware."

http://www.hss.energy.gov/csa/analysis/oesummary/oesummary2008/OES_2008-10.pdf 


\section{Three Recent Events Involved Failed Rigging and Lifting Hardware}

In August and September 2008, three events were reported to ORPS in which rigging (slings) and lifting hardware (eye bolts) failed, resulting in dropped loads, near misses, and, in one event minor injuries to a worker. Each of these events was preventable, and all of them could have had serious consequences.

On September 24, 2008, at the Waste Isolation Pilot Plant, an overloaded synthetic sling failed (Figure 1-1) and struck a waste handling technician across the hand, forearm, and chest The technician received a minor injury (redness of the skin) ORPS Report FM.CAFO..WTS.WTPP.2008.0012)

After remote handling personnel loaded an empty shipping cask onto a trailer, an upper (rear) impact limiter was installed usin two slings and a 25 -ton crane (Figure 1.2). The crane operator was positioned on the northwest end of the trailer in clear view of the operator spotting the impact limiter into position. With the impact limiter in position, two waste handling technicians installed bolts and torqued them, completing installation of the limiter. The crane was maintaining approximately 2,500 pounds tension on the two slings during the installation process. Each synthetic sling was rated at 3.200 pounds and had satisfactorily passed all pre-use inspections.

With the impact limiter installed, the workers positioned themselves to lower the hoist so the rigging equipment could be removed. When the spotter signaled the crane operator to lower the hoist, the operator inadvertently moved the control stick to the hoist (raise) position, instead of the position to lower

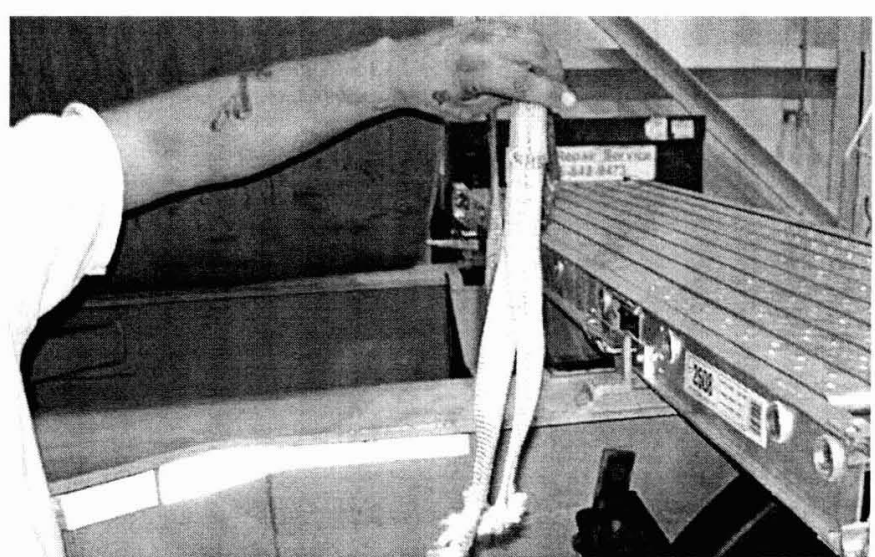

Figure 1-1. Worker holding failed synthetic sling

it, and raised the load higher. A Conduct of Operations mentor positioned at the rear of the trailer noticed that both the cask and trailer were beginning to lift, but before he could call for a stop, the slings broke and struck one of the technicians. Work was stopped and the scene was secured.

Initial investigation revealed that this event could have been attributed to inattention to detail by the crane operator, an improperly positioned load cell, or the lack of sufficient engineered barriers. The exact causes will not be known until the Root Cause Analysis has been completed.

On September 15, 2008, at the Hanford Solid Waste Facility a crane was lifting a retrieved waste cask when the slings used to rig the eask to the erane broke. The waste cask dropped approximately 4 inches and landed in an upright position (Figure 1-3). No one was injured, and the cask was not damaged (ORPS Report EM-RI.-.PIMMC-SOLITWWASTE-2008-0008) 


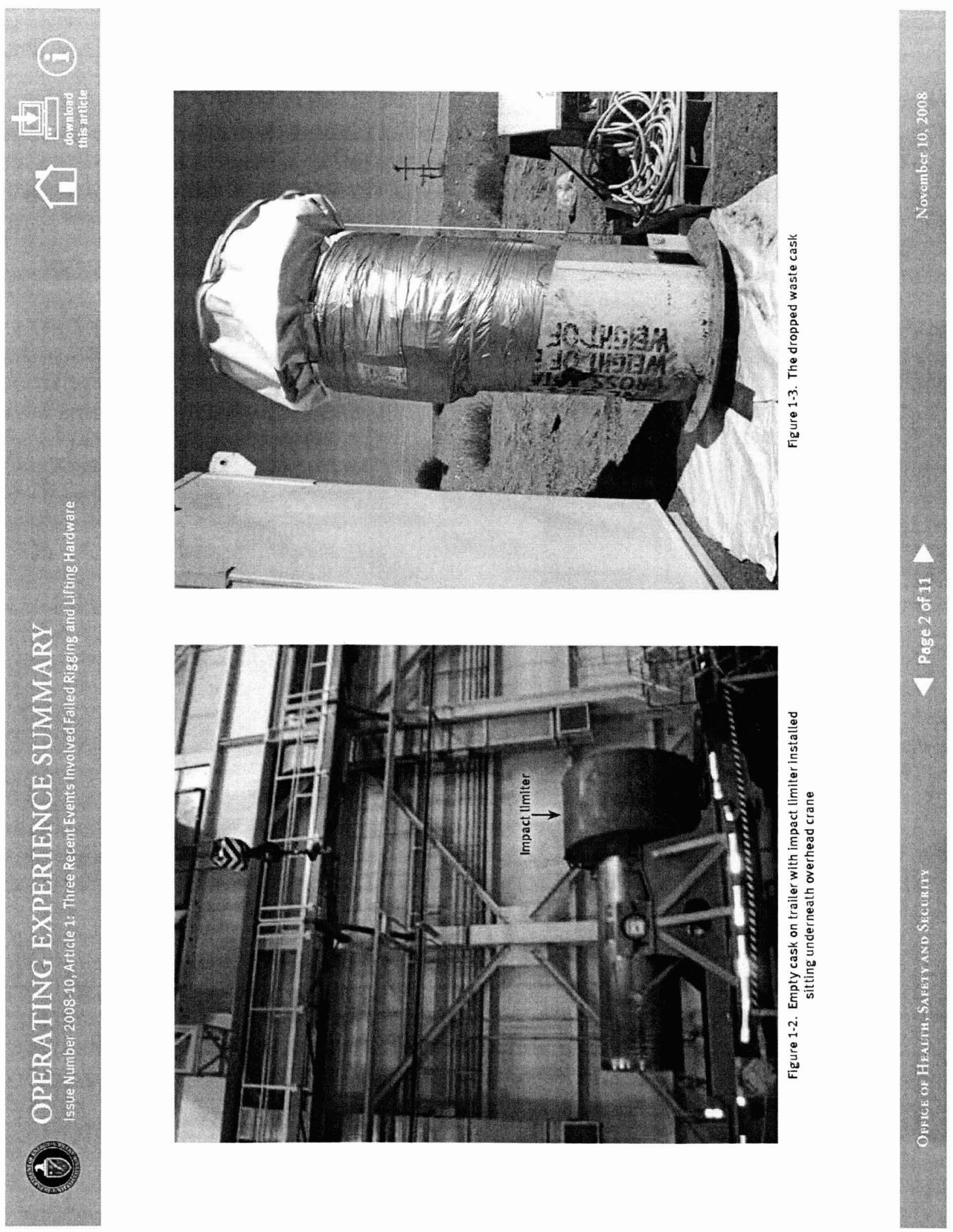


Investigators determined that the synthetic slings selected (Figure 1-4) were inappropriate for the rigging configuration, and softeners had not been used to cushion them. Both conditions increased the potential for the slings to fail.

The load initially was lifted approximately 1 foot to obtain the weight of the cask and was then lifted 3 feet for contamination surveys and removal of dirt. When the surveys were completed. the cask was raised approximately 4 feet to clear the radiological control barrier. During these evolutions, personnel were within 2 to 3 feet of the cask. Fortunately, the slings failed when they did; otherwise, personnel could have been seriously injured.

Investigators determined that the riggers looked at the safe working capacity of the slings in the basket configuration ( 6,400 pounds), not the choked configuration ( 2,400 pounds).

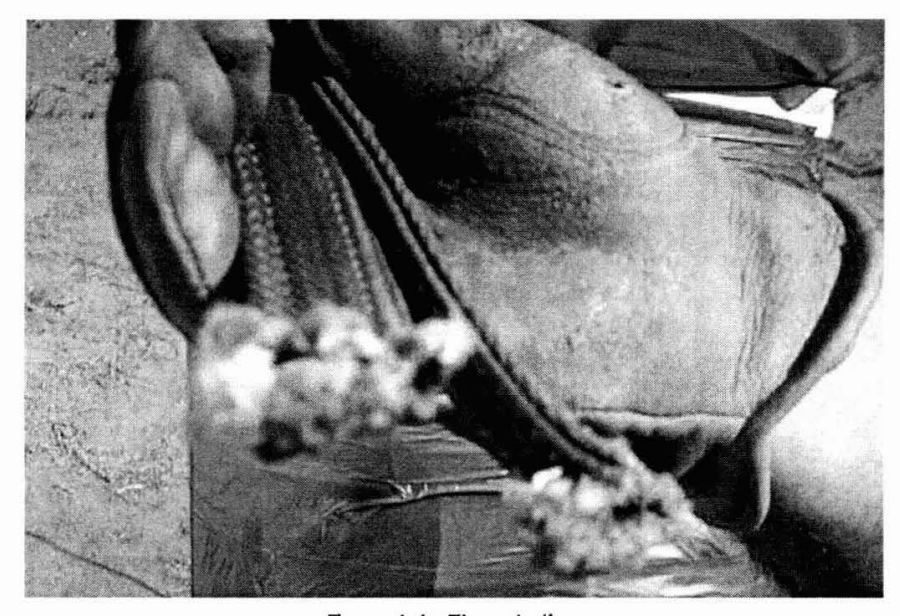

Figure 1-4. The cut sling a total capacity of 4,800 pounds, even though the cask weighed approximately 6,000 pounds. They did not make a second check of the working capacity of the rigging. In addition, the slings were not protected by softeners at the flange interface, which created a sharp corner.

On August 19,2008, at the Hanford High Level Waste Facility a 6,000-pound shield window liner toppled 3 feet to the ground after two lifting eye nut assemblies sheared off from the top of the window liner because of excessive side loading stresses.

Iron workers were attempting to lay the liner on its side when the rigging hardware failed (Figure 1-5). (ORPS Report EM-RP. BNRP-RPPWTP-2008-0016; final report issued September 30, 2008

The shield window liner had to be placed on its side to shorten the legs and jacking bolts had to be added to help with its final positioning in a wall. The drop-forged, heavy-duty eye nuts

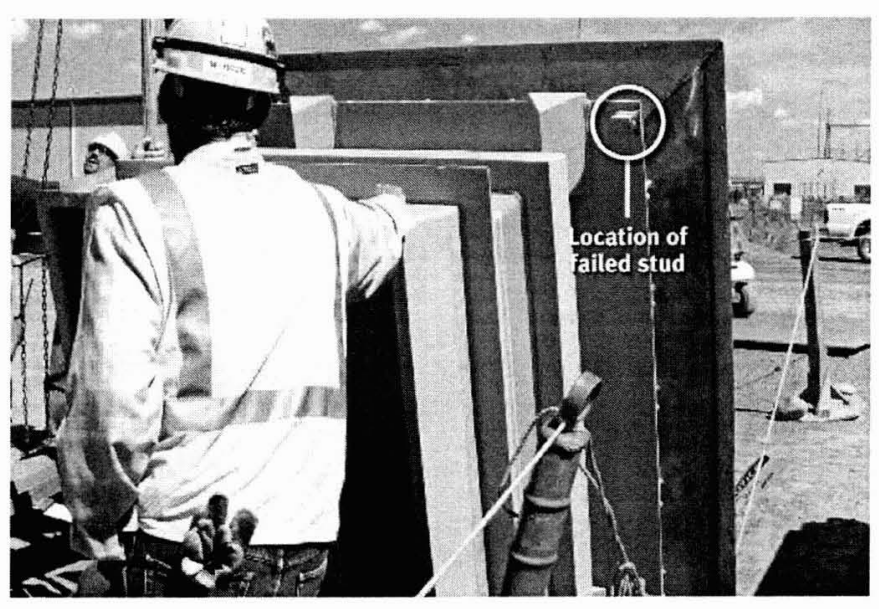

Figure 1-5. Window liner on its side after eye nut stud failure 
(10,600-pound workload rating vertical pull) and threaded studs $(116,000$ psi tensile strength) were installed according to the manufacturer's drawings and shipping instructions. The lifting eye nut was threaded onto a metal stud that was threaded into a welded flange on the liner.

The rigging for the eye nuts was positioned at approximately a 45 -degree angle, and the rigger was using a chain hoist to raise the legs off the ground when the shearing of the two studs occurred. The riggers had successfully performed these side loading lifts in the past on a similar sized window liner with no incident.

Investigators learned that the drawings and specifications provided by Bechtel to the manufacturer lacked the correct rigging configurations and requirements. The drawings did not require the eye nut shoulder to be flush or seated with the flange of the shield window liner. The drawings left a $5 / 8$-inch exposed neck (reveal) on the studs, reducing the overall strength of the eye bolt assembly (Figure 1-6). Figure 1.7 shows one of the failed studs.

Investigators determined that there were no specifications for shear ratings for the studs and that a document review would have identified the lack of lifting or rigging instructions and restrictions. They also determined that there were no material handling directions for the window liners.

Investigators learned that the rigger used a chain hoist with a capacity of 3,000 pounds to lift the window liner assembly, which weighed 6,000 pounds. The rigger should have used a chain hoist with the capacity to match the lift weight. After the configuration of the stud bolts, the chain hoist became the next weakest link in the rigging apparatus. The slings in use for this lift were not an issue.

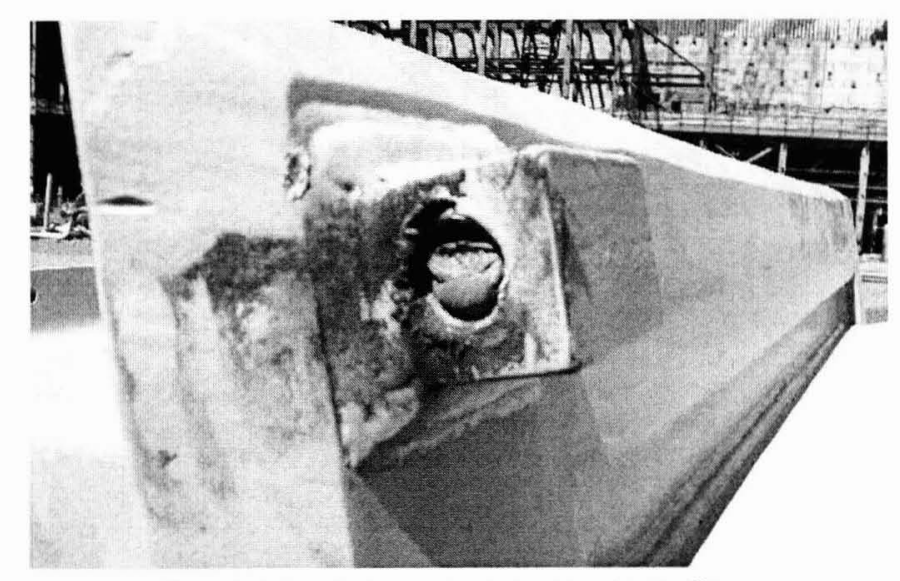

Figure 1-6. Installed eye nut not shouldered to the flange

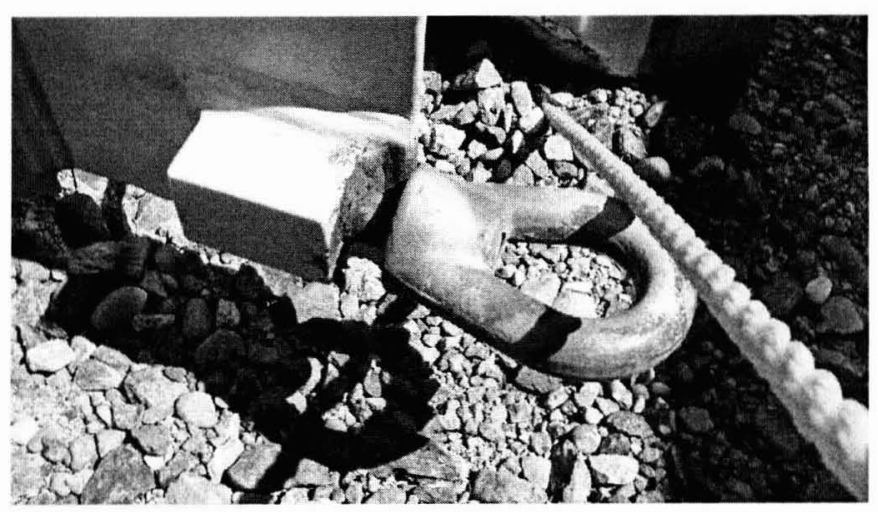

Figure 1-7. One of the four lifting flanges on the liner with a broken stud 
The following guidance is from DOE-STD-1090-07, Hoisting and Rigging Standard (Formerly Hoisting and Rigging

Manual).

- Guidance for proper care and use of slings can be found in Chapter 11, "Wire Rope and Slings." Section 11.3.1.4 of the Standard states that overloading shall be avoided, as shall sudden dynamic loading that can build up a momentary overload sufficient to break the sling. Section 11.3.5.i states that synthetic web slings can be cut by repeated use around sharp-cornered objects. The Standard identifies several types of protective devices that can be used to prevent sling damage.

- Chapter 12, "Rigging Hardware," provides requirements for inspecting, testing, and using shackles, eyebolts, eve nuts, rings, wire-rope clips, turnbuckles, rigging hooks, and load-indicating devices used in hoisting and rigging. Section 12.5.1 of the Standard states that eye nuts shall only be used for in-line loads.
These events underscore the importance of following an approved lift plan and ensuring that the rigging selection and lifting hardware are correctly and properly configured for the lift. The Person-in-Charge should conduct a physical check of the load to verify its configuration and placement of rigging and should also ensure that the load weight has been correctly calculated.

KEYWORDS: Hoisting and rigging, sling, dropped load, near miss, eyebolt,

\section{eye nut}

ISM CORE FUNCTIONS: Define the Scope of Work, Analyze the Hazards, Develop and Implement Hazard Controls, Perform Work within Controls 
RPP-RPT-42583, Rev. 0

\section{APPENDIX E - DOE OPERATING EXPERIENCE SUMMARY}

DOE. Operating Experience Summary, Issue Number 2005-12, Article 1:

"Sharp Edged Load Cuts Rigging Slings."

http://www.hss.energy.gov/csa/analysis/oesummary/oesummary2005/oes2005-12-screen.pdf 


\section{Sharp-Edged Load Cuts Rigging Slings}

On July 11, 2005, at the Idaho Reactor Technology Complex, construction workers were unloading a 5,400-pound concrete ring from a truck when the ring's sharp inner edge cut one of the slings (Figure 1-1) that supported it, causing the other sling to break and the load to drop. No one was near the ring as it dropped, and there were no injuries. The ring cracked and had to be replaced. (ORPS Report ID--BEA-RTC-2005-0002)

The manufacturer casts the concrete rings with a sharp inner edge (Figure 1-2) and two diametrically opposed holes in the mid-point of the outer wall. Long tapered pins are inserted into the holes so the rings can be moved safely after casting, but the manufacturer does not include the pins when the rings are delivered to their customers.

Hoisting and rigging work was identified as a hazard in the job safety analysis, which specified using padding on rough or

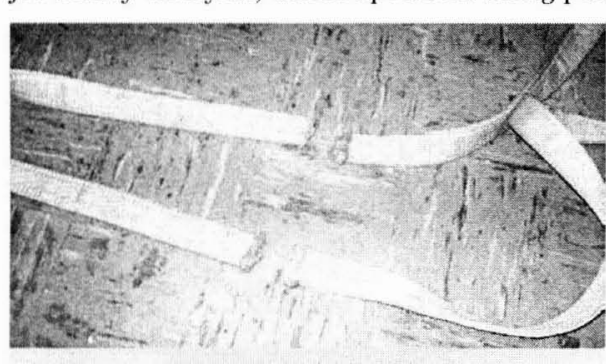

Figure 1-1. Cut slings sharp edges.

The workers

used an

excavator with

a manufacturerinstalled lift

point and two

fairly new, 20.

foot- long slings

in a choker

arrangement.

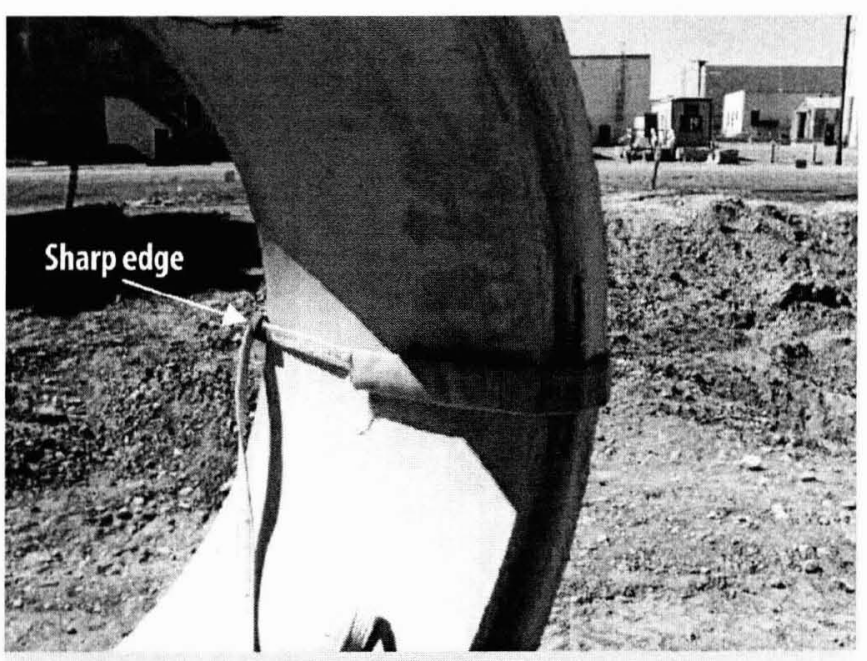

Figure 1-2. Lifting sling configuration

The excavator operator took up the slack in the slings to place the load under tension. Because the worker inspecting the slings thought that they appeared to pull away from the upper edge of the ring, the workers believed that they did not need to pad the upper edge of the ring and placed pieces of old fire hose only on the bottom edge, as shown in Figure 1-2.

The excavator operator lifted the ring about 6 inches above the truck bed and began moving it off the truck. As the ring cleared the truck bed, and the operator began lowering it to the ground, one of the slings was cut; the other failed under the shifted weight, and the ring fell about 3 feet to the ground. Aside from the excavator operator, all of the workers were at least 30 feet away from the ring when it dropped. 


\section{(i. OPERATING EXPERIENCE SUMAMARY \\ Issue Number 2005-12, Atride it Shaip-Ed ged Lond Cuts Rigsing slings}

Hoisting and rigging work stopped so that the event could be critiqued. Work resumed after corrective actions (e.g., improving work planning and load inspection) were developed.

The OSHA Standard for Construction, 29 CFR 1926, contains requirements for padding slings in section 251(c)(9): "Slings shall be padded or protected from the sharp edges of their loads." More specific guidance for using lifting slings is found in the DOE Standard DO()E-STD-1090-2004, Hoisting and Rigging (formerly Hoisting and Rigging Manual). Chapter 11, "Wire Rope and Slings," describes how to protect slings from chafing or sharp edges using padding material such as corner saddles, burlap padding, wood blocks, and leather pads.

A search of ORPS yielded several other events caused by slings that failed on rough or sharp edges.

- On February 17, 2005, at the National Renewable Energy Laboratory, personnel were performing a trial lift of a meta frame holding an extendable-boom forklift weighing about 5,100 pounds when the load shifted unexpectedly and an unprotected rough edge cut one of the slings. One side of the load dropped about 3 feet, but no injuries or damage resulted. The root cause was the rough edge that the workers had noticed, but neglected to protect against. (ORPS Report GO.. NREL-NREL-2005-0002)

- On August 30, 2002, at Rocky Flats, as a subcontractor work group was performing a test lift of a 26,000-pound piece of equipment, a raised metal ridge near the bottom of the base cut the slings, causing the piece to drop about 6 inches. The qualified riggers who prepared the lift underestimated the weight of the piece and used leather work gloves to protect against the ridge, but the gloves proved to be in adequate. No one was injured, and there was no equipment or structural damage. (ORPS Report RFO--KHLL-NONPUOPS1-2002-0003; OE Sunmary 2002-20)
- On August 29, 2001, at the Brookhaven National Laboratory, one end of a Large Hadron Collider magnet fell approximately $4 \frac{11}{2}$ feet to a concrete floor when one of two slings was cut through because of inadequate chafing protection against a sharp edge of the magnet. (ORPS Report CH-BH-BNL-BNL-2001-0023; OE Summary 2001-09)

These events demonstrate the importance of properly planning for a lift. Sharp or rough edges should be padded or softened even if they do not appear to be cutting into the sling. Riggers should know the weight of the load and use padding materials that adequately protect slings from damage.

KEYWORDS: Sling, rigging, near miss, sharp edge

ISM CORE FUNCTIONS: Identify the Hazards, Develop and Implement Hazard Controls 
RPP-RPT-42583, Rev. 0

APPENDIX F -

INCIDENT DESCRIPTIONS AND LESSONS LEARNED

Battelle Energy Alliance, LLC. "Sling Failure During Hoisting and Rigging Activity." Lesson ID: INL-BEA-ID-2009-434. August 11, 2009 


\title{
Sling Failure During Hoisting and Rigging Activity
}

\author{
Priority Descriptor: Blue/Information
}

Lesson ID: INL-BEA-ID-2009-434

Originator: Battelle Energy Alliance, LLC

Date: $8 / 6 / 2009$

Lessons Learned Statement: Ensure wear protection padding used in Hoisting and Rigging activities is selected based on the conditions of the lift. Not all types of wear protection are appropriate in all applications. Use of the incorrect wear protection padding resulted in synthetic sling failure.

Discussion: On June 8, 2009, Maintenance personnel were in the process of off-loading equipment from a truck bed with an overhead crane. Maintenance personnel routinely handle this equipment successfully, and a standard rigging configuration has been developed for this activity. However, this time the equipment was loaded on the truck by the vendor, and it was placed upside down from the normal orientation. This prevented the use of the standard rigging configuration. The alternate rigging arrangement consisted of two synthetic web slings, used in a choke type configuration. The slings were rated at 10.000 pounds each in this configuration. Commercial wear protection pads constructed of reinforced rubber approximately 6 inches by 11 inches, $1 / 8$ inch thick were used in three different places on each of the two slings (total of 6 pads). The wear protection pads were located in areas where the slings contacted the equipment being lifted. While initially lifting the load, a pause was made at approximately 2 inches to check the wear protection positioning. While the check was being made, one of the synthetic slings failed (was severed completely in two), and one side of the 8700 pound load dropped approximately 2 inches back to the transportation trailer bed. The wear protection located at the point of sling failure showed significant scuffing and had been cut completely through as well. The other side of the load remained suspended with no apparent damage to the sling or wear protection pads.

Analysis: Maintenance personnel routinely handle this equipment successfully, but when the equipment was loaded on the truck by the vendor, it was placed upside down from the normal orientation. This prevented the use of the standard rigging configuration. While the need to change the rigging configuration was recognized and the alternate rigging arrangement identified, an adequate evaluation of wear protection requirements was not done. Upon investigation it was determined that the wear protection pads used were designed to prevent scuffing and abrasion, but were not adequate to prevent cutting of the sling. 
ASME B30.9-2006, requires that edges in contact with slings be padded with materials of sufficient strength to protect the sling. The edge need not be "razor" sharp to damage and cut the slings. Compression and tension, combined with a "moderate" edge and nonpositive sling to load engagement, i.e., the sling skipping across the load edge, can result in sling damage. Therefore, it is important to protect slings from damaging load edges which contact the sling. It is also important to realize that wear protection devices will not perform equally well when subjected to abrasion or cutting. Abrasion protection materials, designs and technology should be different from those employed to provide protection from the cutting.

\section{Actions:}

1. Ensure that hoisting and rigging personnel are trained in the selection and use of wear protection devices.

2. When lift conditions change, ensure that wear protection devices are evaluated and that wear protection devices are selected for the specific conditions of the lift.

Contact Name/Phone number: Layne T Wray/ 208-526-6995 / Layne.Wray@inl.gov

References: Occurrence Report NE-ID-BEA-SMC-2009-0005; ASME B30.9-2006;

DOE-STD-1090 
RPP-RPT-42583, Rev. 0

\section{APPENDIX G - \\ NAVY CRANE CENTER TECHNICAL BULLETIN}

NAVFAC. The Crane Corner: Navy Crane Center Technical Bulletin. 54 ${ }^{\text {th }}$ Edition, June 2007. https://portal.navfac.navy.mil/portal/page/portal/NAVFAC/NAVFAC WW PP/NAVFAC_NCC _PP/FILES/54EDWEB.PDF 


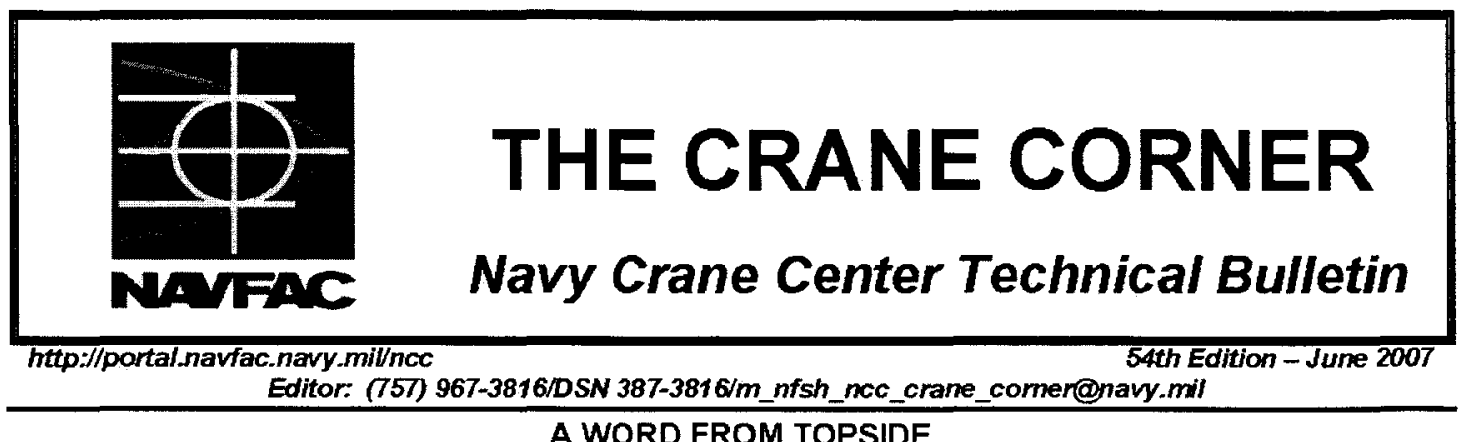

\section{A WORD FROM TOPSIDE \\ Sam Bevins}

Thus far, in FY2007, Navy shore activities are showing a very positive trend in the reduction of crane accidents. Through the first seven months of this fiscal year, crane accidents are down by almost 25 percent over the same time period last year. If our activities can continue this positive trend through the always challenging summer months, we can have our best year yet for Navy lifting and handling safety.

One area of concern, however, is the percentage of accidents that involve the operation of mobile cranes. We keep a close watch on mobile crane accidents since they can have a greater potential for serious consequences than other types of cranes. Serious accidents, such as two blockings, contact with overhead power lines, and overloads (with the resulting loss of stability) are a frequent threat with mobile crane operations. For FY04, 05, and 06, the percentages of accidents that involved mobile cranes consistently decreased from 39 to 33 to 28 percent respectively. This year, this percentage has crept back to 37 percent. While our activities are reducing accidents with other types of cranes, we are not seeing similar reductions in mobile crane accidents.

Some types of accidents are more common with mobile cranes than with other crane types. Wire rope damage was reported on seven accidents. The wire rope may jump off a boom tip sheave or be damaged on the drum from mis-spooling due to improper operation. Two-blocking is an all too frequent occurrence, usually with no load on the hook as the crane is being set up for operation or shut down for transit at the end of the shift. Environmental conditions can have more of an effect on mobile cranes than other types of cranes. Wind and wave action were contributing factors in four of the accidents. Two common ship support lifts where mobile crane accidents occur are brow lifts and shore power cable lifts. Five of the reported accidents occurred during these lifts.

Operational risk management is vital for every mobile crane operation. Properly identifying and assessing all the risks associated with the crane itself, the lift site, the load to be handled, the crane team, environmental conditions, and other influencing factors can be a challenge.

Our video, Mobile Crane Safety, covers seven topics: laying a foundation for safety, teamwork, crane setup, understanding crane capacities, rigging considerations, safe operating procectures, and traveling and securing mobile cranes. The video is available at $\mathrm{http} / /$ /dodimagery.afis.osd mil/(DAVIS/DITIS) (PIN 806721). This is a worthwhile training aid to help ensure mobile crane lifts are properly planned and executed.

Inside This Issue

A Word From Topside. Page 1

UFC 3-320-07N, Weight Handling Equipment,

Page 2

Back-up Monitoring System. Page 2

CSAS \& EDMs. Page 3

Second-Quarter FY07 Accident Report, Page 5

NAVFAC P-307 Web Based Training. Page?

Crane Awareness for the Summer Months, Page 7

2007 Weight Handling Improvement Conference.

Page 8
Mobile crane safety is critical to fleet readiness and to the personal safety of everyone in the vicinity of a mobile crane operation. Take the time to properly assess all the risks. Make the right risk decisions. Let's have our best year yet for mobile crane safetyl 
of operational risk management (ORM) were not employed to mitigate the risks associated with possible wind gusts on a day when the reported sustained wind conditions exceeded $15 \mathrm{mph}$.

Lessons Leamed: Environmental factors (wind, rain, etc) must be considered prior to and during crane operations. The operator and personnel performing rigging functions are responsible to ensure the load is safe to lift, properly secured, and properly controlled. If there is doubt, stop the operation until conditions improve or request assistance.

\section{PERSONAL INJURY}

Accident: During removal of a brow, a rigger was struck in the head by a hinged walk ramp. A crane team was assigned to remove a brow and shore power cables from a ship that was preparing to get underway. Time constraints increased the operational tempo of the crane team. After successfully removing the shore power cables, the crane team used a four point pick to lift the brow. The brow had a hinged walk ramp on one end. An individual on the ships deck raised the walk ramp and held it until the brow was raised and rotated away from the ship. As the brow was lowered to the ground, the walk ramp opened and struck one of the riggers in the head. The ramp was not secured to the brow to prevent movement and the crane team did not check the condition of the ramp prior to lifting the brow. Tag lines were not used. The injured rigger was standing in close proximity to the suspended load. Personal protective equipment (hard hat) was worn and it likely prevented serious injury.

Lessons Learned: Rigging personnel must make sure all latches, ramps, and other attachments are secured before the crane moves any equipment. Crane team personnel should avoid placing themselves in unsafe positions near suspended loads. The use of taglines reduces the need to be near a suspended load. Wearing of personal protective equipment is an effective tool in reducing the potential for serious injury. Crane team supervision must ensure that work tempo does not degrade operational safety.

\section{TWO-BLOCKINGS}

Accident: During the operation of a category 4 truck mounted boom crane, it was two-blocked. The crane was positioned with the boom to the rear and over the truck bed. The hook block was in the OEM designed stowed travel position which deactivated the anti-two block function. In order to make a lift, the operator had to reposition the boom over the front of the truck. The operator raised the boom approximately 30 degrees and then rotated the boom 180 degrees. During the movement, the operator two-blocked the crane. The subsequent investigation determined that the operator inadvertently operated the extend boom control when he intended to operate the hoist down control. The force applied by the extension of the boom, damaged the wire rope. The qualified operator had not operated the equipment for some time and failed to reacquaint himself with the controls or operational characteristics prior to starting the work or prior to any form of an operational check.

Lessons Learned: Trained operators must reacquaint themselves with the controls or operational characteristics of the equipment, especially. After periods of non-operation. For mobile cranes that do not provide protection against two blocking or when anti-two block functions are bypassed to stow or travel, activities must develop crane specific procedures to minimize the possibility of two-blocking.

\section{SIGNIFICANT CONTRACTOR ACCIDENT}

Accident: During the installation of a new double girder bridge crane, a girder was dropped after a rigging gear failure. Several contractor employees sustained serious injuries. A contractor was utilizing a mobile hydraulic crane to set the girder in place. The $22.5 \mathrm{k}$ pound girder was rigged with two $20 \mathrm{ft}$ polyester round slings, each with a rated capacity of $17 \mathrm{k}$ pounds. After the girder had been suspended in a static position for approximately 10 minutes, one of the two slings failed. The other sling likely failed due to overload. Both slings were 
believed to have been protected by rubber matting that was used as chafing material. Based on the break location and the condition of the chafing material, the most probable cause of the sling failure was due to inadequate protection of the sling from the sharp edges of the girder.

Lessons Learned: Synthetic slings can be easily cut at sharp corners or edges. Adequate chafing protection is required for synthetic slings where there is a possibility of the sling being cut or otherwise damaged by the load. In the accidents noted above, the protection was inadequate. Chafing material must be of sufficient thickness and strength to prevent sling damage. Synthetic rope slings and alternate yam synthetic round slings require a specific radius of curvature around sharp cornered objects (see NAVFAC P-307, section 14). This requirement also applies to the minimum radius of curvature at corners of objects being lifted. With high stresses on the slings, soft chafing material may not maintain the minimum required radius or provide the required protection. Harder materials, such as split piping sections or special rounded shoes, are recommended. Sling manufacturers also provide wear protection products that protect slings from sharp corners or edges. Also, ensure the rigging configuration is stable and slings cannot slide off the chafing protection. In addition, ensure synthetic slings are not excessively bunched in the bowl of the hook or in shackles. This can cause uneven loading on the synthetic fibers and failure of the sling. Finally, synthetic slings must be properly cared for and stored. Navy crane center auditors find more synthetic slings in poor condition than any of the other types of slings.

Weight handling program managers and safety officials are encouraged to review the above lessons learned with personnel performing lifting and handling functions and consider the potential risk of accidents occurring at your activity. OPNAVINST $3500.39 \mathrm{~B}$ prescribes methods for assessing hazardous operations which should be used in the planning and preparations of all WHE lifts.

E-mail submission of reports of accidents, unplanned occurrences and near misses is encouraged. The e-mail address is nfsh_ncc accident@navy.mil. The reports must include a complete and concise situation description, corrective and preventive actions, probable cause and contributing factors, and an assessment of damage. For equipment malfunction or failure, include specific description of the component and the resulting effect or problem caused by the malfunction or failure.

\section{NAVFAC P-307 Web Based Training}

Two courses have been added to Navy Crane Center's growing list of web-based training courses: Crane Rigger and Rigging Gear Inspection. This brings the total number of web-based training courses to five, which also includes: General Crane Safety Refresher, Category 2 Crane Safety Refresher, and Category 3 Crane Safety. Four more courses [General Crane Safety, Category 2 Crane Safety, Category 4 Crane Safety, and Load Test Director] are scheduled to be converted to web-based format and made available online during the next several months. Maintenance courses will be converted over the next 1-2 years. Web-based courses are available online through eLearning on Navy Knowledge Online (https:/www.nko.navy.mil). Training information including course summaries, schedules, billeting, and online information can be viewed on Navy Crane Center's web site at https://portal.navfac.navy.mil/ncc (click on training).

\section{CRANE AWARENESS FOR THE SUMMER MONTHS}

As we approach the summer months, I again ask weight handling managers and supervisors to place a special focus on safe crane and rigging operations. Overall, the navy shore based crane accident statistics have been trending downward as compared to last year and we have an opportunity to make FY07 the safest year on record. However, the summer months bring us a real challenge to maintain this downward trend. With the added distractions associated with the warmer weather, maintaining a sharp focus on the critical job at hand during weight handling operations will be challenging. Surveillance of lifting and handling operations by experienced personnel has proven to be an effective tool in accident prevention. During surveillances, look for 
RPP-RPT-42583, Rev. 0

\section{APPENDIX H - INCIDENT DESCRIPTIONS AND LESSONS LEARNED}

Nuclear Regulatory Commission. "Browns Ferry Nuclear Plant NRC Integrated Inspection Report." January 2005.

http://www.nrc.gov/NRR/OVERSIGHT/ASSESS/REPORTS/bf 2004005.pdf 


\section{b. Findings}

Introduction: A Green self-revealing NCV was identified for the Failure to Comply with 10 CFR 50 Appendix B, Criterion V, Instructions, Procedures and Drawings. As a result of an inadequate procedure and poor human performance, a Reactor Building crane trolley drop occurred.

Description: On October 24, licensee and contract personnel were conducting work using WO 04-716728-000, the implementing work document, for Design Change Notice (DCN) 60600 to upgrade the common Reactor Building 125-ton bridge crane. Part of the DCN was to replace the 65000 -pound trolley with a new one. During the rigging process to remove and lower the old trolley from the overhead to the Unit 1 refueling floor, one synthetic sling failed and one end of the trolley dropped approximately four feet to the concrete floor. The force associated with the drop resulted in the failure of one of the two remaining slings on the other end of the trolley. Operations and engineering personnel immediately performed a series of detailed inspections and determined that no plant operability or safety issue resulted. The licensee determined that the event did not challenge the safe operation of Units 2 and 3 or cause entry into any Limiting Conditions of Operation. The drop resulted in surface cracking and spalling of the concrete ceiling beneath the point of impact on the Unit 1 refueling floor. The licensee assembled a root cause investigation team to review the event and determine its root cause. The licensee also commissioned the services of an independent structural engineer to analyze the structural integrity of the floor at the point of impact to determine if the floor still met its design criteria.

The inspectors completed a walkdown of the affected areas, accompanied by a civil engineer from the licensee's staff, to view the cracked and spalled concrete from the ceiling below the point of impact. The inspectors also toured the plant and the main control rooms to assess the condition and status of safety-related systems. The inspectors discussed the issue with licensee management, engineering, and operations personnel to assess immediate actions taken and gain an understanding of the detailed inspections completed by licensee personnel. The inspectors also assessed compliance with the reporting requirements of NUREG-1022, Event Reporting Guidelines.

The inspectors later reviewed the licensee's root cause determination report to assess details, accuracy, and short and long term corrective actions. The inspectors noted that the root cause report was thorough, detailed, and comprehensive. The planned and completed actions were appropriate and comprehensive. The licensee identified several root and contributing causes. Root causes included inadequate work practices by the contractor support personnel, and improper installation and verification of the rigging in that the synthetic slings used in the lift were not adequately protected.

The inspectors compared the root and contributing causes with information obtained from the review of licensee work control documents, procedures, briefing papers listed in the attachment, and discussions with licensee personnel. The procedure to remove 
the old trolley and install the new trolley was revised several times prior to its implementation. However, the rigging crew was not made aware of the final revision and did not implement all of the requirements to use "softeners" to protect the slings and that a line of sight be maintained to ensure that their effectiveness was maximized.

A single sling was rigged around the trolley support beam with five protective softeners. The softeners were verified at the beginning of the move but not during the move, as specified by the rigging permit. Photographs showed that at least one softener at the trolley beam was not in a position to protect the sling after the load was applied. As the old trolley was lowered close to the new trolley, which was staged in preparation for its installation, workers were concerned about possible interference between them. The contract project lead engineer determined that there would be additional clearance if one end of the old trolley was lowered. There was no discussion or intervention by the TVA task manager, supervisor, or safety observer, even though at the pre-job briefing it was emphasized that the load was to be maintained level. The trolley descent had been halted several times to level the load. When one end of the trolley was lowered, the edge of the trolley beam cut the single rigging sling and the trolley fell. Almost immediately, one of the slings on the other end of the trolley failed and the trolley fell to the refuel floor.

Analysis: The inspectors determined that the licensee's inadequate procedure and poor work performance which resulted in the Reactor Building crane trolley drop that occurred on October 24,2004 , constituted a performance deficiency and a finding. This finding is greater than minor because it is associated with program and process attributes and affected the objective of the Initiating Event Cornerstone to limit the likelihood of those events that upset plant stability and challenge critical safety functions during at-power operations. In addition, if left uncorrected, this finding would result in a more significant safety concern because structural damage to the refuel floor as well as potential damage to the spent fuel pool would occur if the load had dropped from a higher elevation. This finding did not represent an immediate safety concern. This finding was evaluated using the SDP and was determined to be a finding of very low safety significance because no initiating event or transient actually occurred, there was no permanent structural damage to the refuel floor, there was no functional degradation, and mitigating capability was not affected. The inspectors also determined that the cause of this finding was related to the human performance cross-cutting area.

Enforcement: 10 CFR 50 Appendix B, Criterion V, states, in part, that activities affecting quality shall be prescribed by documented instructions, procedures, or drawings of a type appropriate to the circumstances and shall be accomplished in accordance with these instructions, procedures, or drawings. Contrary to the above, inadequate procedures (not using the latest approved revision to the procedure) and poor human performance resulted in the drop of the Reactor Building crane on October 24, 2004. Because this failure to comply with 10 CFR 50 , Appendix $B$, Criterion $V$, is of very low safety significance and has been entered into the licensee's corrective action program, as PER 70752, this violation is being treated as an NCV, consistent with Section VI.A of the NRC Enforcement Policy: NCV 05000260, 296/2004005-02, Inadequate Procedure and Poor Human Performance Resulted in a Drop of the Reactor Building Crane Trolley. 